\title{
Evaluation of Models for Longevity in a Closed Nucleus Breeding Programme: A Case Study Kenyan Sahiwal
}

\author{
Benjamin Musyimi Musingi ${ }^{1,2 *}$, Leah Mumbi Mahianyu ${ }^{3}$, E. Dorcas Mutheu Musingi ${ }^{4}$ \\ ${ }^{1}$ Animal Breeding and Genomics Group, Department of Animal Sciences, Egerton University, Egerton, Kenya \\ ${ }^{2}$ Department of Biological Sciences, Egerton University, Egerton, Kenya \\ ${ }^{3}$ National Police Service, Department of Kenya Police, Njoro, Kenya \\ ${ }^{4}$ Department of Building and Civil Engineering Water Section, Technical University of Mombasa, Mombasa, Kenya \\ Email: *Musyimi.b@gmail.com
}

How to cite this paper: Musingi, B.M., Mahianyu, L.M. and Musingi, E.D.M. (2021) Evaluation of Models for Longevity in a Closed Nucleus Breeding Programme: A Case Study Kenyan Sahiwal. Open Journal of Animal Sciences, 11, 269-291.

https://doi.org/10.4236/ojas.2021.112021

Received: March 11, 2021

Accepted: April 25, 2021

Published: April 28, 2021

Copyright (c) 2021 by author(s) and Scientific Research Publishing Inc. This work is licensed under the Creative Commons Attribution International License (CC BY 4.0).

http://creativecommons.org/licenses/by/4.0/

\section{Open Access}

\begin{abstract}
Longevity and stay ability are parameters in any breeding programme. The Overstaying of any animal on a farm has got negative effects on the farmer. Short stay also means early exit of good animals that could have been used for a longer time and more productive. The intention of this review paper is to emphasize the importance of models that an upcoming breeding program can use without affecting the quality of the herd. In this paper, longevity is taken purely on the performance measure. The functional and type traits of longevity should be studied further before all models are put into play. But the case of closed breeding programmes, performance traits are easily measurable because many animals will exit the herd as they have been sold to farmers hence many functional straits will be expressed outside the herd. Genetic evaluation of the Kenyan Sahiwal should account for inbreeding. This study has also provided genetic and phenotypic parameters to enable the inclusion of longevity in the breeding objective for the Sahiwal cattle improvement programme.
\end{abstract}

\section{Keywords}

Linear Models, Longevity, Sahiwal, Threshold Models

\section{Introduction}

Longevity or the age at which a cow leaves the breeding herd is a trait of great economic importance in dairy and beef cattle breeding [1]. Productive longevity can also be described as the number of calving's per female [2]. In beef and dairy 
cattle, longevity plays a considerable role in the farm economy by increasing the profit realized per cow and enables greater response to selection because fewer animals exit the herd due to involuntary culling [3], a situation that provides greater selection intensity among females, and surplus heifers for sale [1].

\subsection{Selecting for Longevity}

Although milk production is considered as the single most important trait in dairy farming, cattle breeding programmes are changing their breeding objectives to include longevity and other traits (type and functional) [1], so that cows can meet the challenges associated with high milk production. Direct selection for longevity results in improved health and fitness [3] and even milk production of cows [4]. Longevity is also associated with decreased cases of involuntary culling due to reproduction, udder health, and workability [5]. Decrease in involuntary culling is accompanied by an increase in voluntary culling due to low production. Therefore, breeding for longevity is considered to have ethical and economic benefits since it results in favorable response in profitability of beef and dairy cattle enterprises [3].

However, inclusion of longevity in the breeding objective is hampered because the trait is low heritable [4] [6]. Estimates of heritability for longevity are defined variously based on the length of time interval for survival after first calving range from 0.002 to 0.031 [6]. When defined as total milk production over all lactations, number of lactations initiated, total number of days in lactation over all lactations, the time between birth and last milk recording in months; and time from first calving to last milk recording in months, the estimates ranged from 0.05 to 0.18 [4]. Thus, heritability estimates for longevity regardless of how the trait is defined or analyzed are low, implying that direct selection may not yield significant gains [4].

Another limitation of selecting directly for longevity is the delay in availability of phenotypic information [7], which may lead to increase in generation interval [8]. The age at exit from a herd has been reported to be around 80 months from birth or 54 months from first calving [4], delaying the time in which information on exit from the herd is obtained. Information on other measures of longevity such as lifetime milk production, number of lactations initiated, total days in milk is also available once a cow exits the herd. Availability of traits expressed early in life and which are favorably correlated to longevity can be useful in selecting for this trait. Genetic correlations between longevity and linear and fertility traits have been reported to be low to moderately positive [4] [9] [10]. Such traits can be used in breeding programmes to indirectly select for longevity early in an animal's life, leading to improvement in longevity and reduction in generation interval.

Reproductive performance is a crucial component of culling criteria and therefore influences longevity in cattle herds and is regarded as the single most economically important trait in cattle [11]. Poor reproductive performance leads 
to increased involuntary culling, fewer lactations initiated and calves born and less milk in a cow's lifetime, as well as increased cost of replacement. Therefore, since productive longevity is closely related to fertility, it is important to consider the genetic effects of both traits simultaneously. Other traits which influence culling decisions such as body conformation type traits have also been considered as proxy for longevity [4] [12]. Despite its importance in cattle, longevity has not been studied in the Sahiwal cattle and has not been recommended for inclusion in the breed's breeding objective [13] [14] [15].

Since direct selection for longevity is not feasible partly due to delay in acquisition of data, correlated response due to selection on traits that are genetically correlated with longevity should be explored. Favorable associations between longevity and linear type traits have been reported, indicating selecting for these traits would improve longevity [4]. Based on phenotypic relationships, [12] found those type traits were not a good indirect indicator for a productive life. However, there seems to be an important influence of the definition of longevity on the associations reported [4]. Fertility traits such as number of services per conception, difficulties in calving, days open and other fertility traits were reported to influence longevity significantly [11]. Estimates of genetic correlations between longevity and other performance traits, which can be used as selection criteria for longevity in the Sahiwal breed in Kenya are lacking.

Whereas the current quest is to improve longevity, the trait and other correlated traits are negatively affected by inbreeding in livestock populations. Longevity and reproductive performance have been shown to decrease while, rate of disposal or loss of replacement heifers before first calving, age at puberty increased due to inbreeding through reduced growth [16]. Studies of inbreeding depression on longevity are rare. However, for every increase of $1 \%$ in inbreeding, productive life has been reported to decrease by about 13 days according to the Canadian Dairy Network [17]. Cows with high inbreeding levels have also been reported to have a higher risk of being culled [18]. Effects of inbreeding on non-production traits include decreased reproductive efficiency and decreased stay ability. The negative effects on traits related to fitness have been attributed to reduced heterozygosity as inbreeding accumulates [19].

Inbreeding level and rate of inbreeding in the Sahiwal cattle population in Kenya has been found to be on an upward trend and is above 1\% [20]. It is therefore expected that there will be depression in production and functional traits such as fertility and longevity. Inbreeding depression depends not only on actual level of inbreeding but also on the rate of inbreeding. At a slow rate of inbreeding per generation, natural selection counteracts the effects of inbreeding by removing the less adapted inbred animal [21]. Therefore, animals with the same level of inbreeding may have different inbreeding depression effects depending on the completeness of their respective pedigrees [22]. The quality of pedigree can be accounted for by estimating the rate of inbreeding [22]. Estimated this way, the estimated coefficient corrects for depth of the pedigree depth 
of an individual and indicates the increment in inbreeding regardless of number of known generations in its pedigree [22].

\subsection{Importance of Longevity in Sahiwal Breeding Programme}

Inclusion of longevity in breeding objective of cattle is hampered by the delayed availability of phenotypic information. Genetic correlations between longevity and traits expressed early in an animals' life which can be useful in selecting for longevity have not been estimated [23]. Further, though inbreeding levels for Kenyan Sahiwal breed have been on an upward trend due to selection in a closed nucleus with small effective population size, inbreeding depression for longevity and fertility traits in the Sahiwal population in Kenya has not been assessed. Consequently, the long-term sustainability of the Sahiwal breeding programme is threatened due to reduced viability of the population and variance of genetic gains across generations [23].

\subsection{History of Sahiwal}

Sahiwal is humped zebu cattle that originated from India and Pakistan. The breed was imported into Kenya between 1939 and 1963 to improve the performance of the local East African zebu [24]. The founding population consisted of 60 bulls and 20 cows which were introduced in Livestock Improvement Centres (LICs) across the country. After some basic performance evaluation, the best animals from the LICs were taken to Naivasha to establish the National Sahiwal Stud (NSS) in 1963. Breeding of this population followed a closed nucleus after the recommendation for genetic improvement of milk and growth rate [98]. To date breeding of the Sahiwal has been under a closed nucleus breeding programme except for the introduction of semen from Pakistan in 1992 [25].

In Kenya, the breed is favored by the Maasai pastoralists due to its high milk production and growth as well as good reproductive ability compared to the local zebu [14] [25]. Therefore, the breed is a very important dual-purpose cattle breed for pastoral and mixed farming communities in the Eastern African region [24]. The breed fits well within the harsh rangelands of East Africa because the agro-climatic conditions of these rangelands are similar to the breed's original habitat in the Punjab region of India and Pakistan [24].

\subsection{Sahiwal Cattle Production Systems in Kenya}

The Sahiwal cattle in Kenya are mainly raised by Maasai pastoralists in the Arid and semi-arid areas of Kenya. However, pure Sahiwal cattle are found in government and private ranches [13]. The government and private ranches form the nucleus of the Sahiwal cattle breeding programme in Kenya. The breeding strategies adopted are pure breeding by the nucleus herds and crossbreeding among the pastoralists. The nucleus herds, therefore, produce bulls for pure breeding and crossbreeding in the pastoral herds. Breeding takes place under a closed nucleus, where movement of genes is unidirectional, from the nucleus to the 
pastoral herds, which form the commercial population. Cattle in the pastoral herds as well as those in government and private herds are raised under low input production systems where the purpose is for tangible and intangible benefits [13]. The main aim of Sahiwal farmers in the different production systems is to increase milk yield, body size and mature weight. Good fertility and adaptation to local production conditions are also considered [14].

\subsection{Breeding Objective for the Sahiwal Cattle in Kenya}

Before any genetic improvement programme is implemented, the breeding objective must be defined [26]. The breeding objective comprises traits which the producer attempts to improve genetically because they influence returns and costs. Development of breeding objectives involves specification of the breeding, production and marketing systems, identification of sources of income and expense, identification of biological traits influencing revenue and costs, derivation of economic and biological values, estimation of genetic and phenotypic parameters and prediction of genetic gain. For the Kenyan Sahiwal, these steps have been covered in recent studies [13] [14].

The breeding objective for the Sahiwal cattle, which targets traditional markets, includes sale weight $(\mathrm{kg})$, lactation milk yield, feed intake, age at first calving, cow weight, calving interval, pre-weaning survival, post-weaning survival and productive lifetime. The breeding objective as presently defined [14] [15] includes a measure of longevity, but it is important to note that genetic parameters of longevity for the population are lacking. Use of parameters from other livestock populations, albeit being raised under the same production system or climatic conditions as the Sahiwal cattle, as in any other improvement programme implies that the trait may be influenced by other traits indirectly, resulting either in a favorable or unfavorable genetic change [4]. Therefore it is important to estimate genetic parameters for the Sahiwal cattle in Kenya and its relationship with other breeding goal traits.

\subsection{Definition of Longevity}

Longevity traces time from a defined starting point up to the occurrence of an event [27] [28] [29]. In the context of this paper, the defined starting point can be the time of birth or first calving up to the last test day record or last day in milk, or the time when an animal exits a herd. Longevity can be true or functional longevity. Functional longevity is the ability of a cow to delay culling on whatever basis, other than milk production. The implication in this case is that the animal has above average health, fitness and fertility [30] [31]. Measures of functional longevity include number of lactations, age from first calving to last day in milk, length of productive life and lifetime production [27]. The uncensored definitions of longevity are based on age at the exit, either through culling or death.

Censored definitions of longevity are related to survival to a pre-determined age within or across lactations [32] [33]. Defined this way, longevity can be 
scored as a binary trait, where animals are scored as to whether they survived to a given age or not [34] [35]. The trait can be analyzed using linear regression models [36] [37] or threshold models [34]. The period can be limited to within lactation [34] or across all lactations [6]. This definition is limited by the fact that only animals that survive to a given age are included in the genetic analysis, while those which are still surviving are left out [38]. Further, animals that left before the specified period are excluded since they are considered missing [36]. Longevity can also be regarded as stay ability, which is the probability that a cow will survive to a certain age if it is given the opportunity to attain that age [39]. Another definition is the time in days between calving's, or from one calving to death or culling [40]. Other definitions of longevity include number of days from calving to culling, death, censoring, or second calving (herd life in the first lactation) and number of days from calving to culling, death, censoring, or sixth lactation (herd life in the first five lactations). Survival scores for the first five lactations or survival to 365 days ( 0 if a cow was culled before 365 days or 1 if it reached at least 365 days) [34] have also been used to define longevity.

\subsection{Importance of Longevity in Cattle Breeding}

Removal of a cow from the herd occurs primarily due to reproductive failure, production of poor-quality calves, or low milk production. The importance of longevity is clearly understood when viewed against the value of removal and the cost of replacement. In beef cattle, a cow's peak performance and profitability are about 9 years of age. From a production perspective, the optimal age of exit from a herd has also been found to be about 9 years of age [3]. From an economics perspective, selecting for increased longevity has a positive impact on profitability of cattle enterprises [3] through lowered costs of replacement. Despite its importance in cattle breeding, longevity is not considered in routine genetic evaluation of Sahiwal cattle and its genetic parameters have not been estimated [14] [15]. Recently, higher production costs have led to an increase in prices of calves, cattle, and beef prices are pushing the costs of purchasing replacement cows and heifers up. To counter this trend cows can be selected for a longer productive life. Selecting for longer productive life leads to a positive economic impact [3].

\subsection{Economic Value of Longevity}

As a trait, longevity has many definitions, all of which aims at describing the importance of an animal's lifespan in relation to its contribution to profitability of a herd [41]. Regardless of the definition adopted, it is generally agreed that longevity is a trait of major economic importance in cattle and greatly influences herd profitability [42] [43] [44]. Longer longevity is an indication of lower incidences of involuntary culling and implies an increased proportion of higher producing mature cows in the herd leading to improved herd production [45]. A positive consequence of this herd structure is that replacement requirements are 
lowered, meaning more surplus heifers are available for sale. Cow maintenance costs are also spread over a large number of offspring [46]. The higher selection intensity among cows is possible since involuntary culling and replacement requirements are reduced.

Numerous cattle breeding programmes have incorporated longevity in their breeding objectives due to their high economic importance [1] [41] [44]. As breeding programmes focused on increasing yield, there has been an associated decline in fitness traits such as longevity, udder health and fertility. This has necessitated inclusion of such traits in the breeding objectives for many cattle breeding programmes. Increase in longevity has been found to result in increased profits in various cattle breeding programmes [1] [47], although it was found to be breed dependent [1]. By definition, the economic value of a trait is the expected increase in profit due to a unit improvement in the genetic merit of a trait when all other traits in the breeding objective are held constant [48]. It can also be defined as the change in farm profit per cow per year due to a unit change in genetic merit of the trait of interest [49].

\section{Direct Selection for Longevity}

In cattle herds longer productive herds mean that few replacement heifers are required [50]. Replacement of cows by heifers in a herd is necessitated by involuntary factors of production, such as problems related to udder ligaments, angulation, diseases, infertility and low speed of milking [51]. On the other hand, cows can be disposed of through voluntary culling due to low production of milk [11]. Involuntary disposal is an indicator of the status of animal welfare and is therefore done to reduce suffering. However, a high rate of involuntary culling in most cases is indicative of underlying problems associated with herd management [52]. The price of the culled cow is usually lower than that of the replacement heifer, meaning that involuntary culling is a costly strategy [51]. Some of the criteria used in cow herds to select animals for disposal include poor fertility, serious health problems, high somatic cell count, physical defects and low production [53].

Heritability estimates for longevity regardless of how the trait is defined or analyzed are low [4] [6] [54]. However, due to its great relative economic importance in cattle [1], longevity is being included in the breeding objective of cattle breeding programmes. Even though it has a low heritability estimate, direct selection for longevity may yield significant gains [4], especially when generation interval is considered.

\section{Indirect Selection for Longevity Based on Linear Type Traits}

Due to the realization of the importance of longevity, most breeding programmes are changing to include longevity in their breeding goals [1] [33]. However, direct selection for longevity is limited by the long time needed to obtain the re- 
quired information, sometimes after the death of the cow and low heritability, ranging from 0.03 to 0.13 [37] [55]. Although milk production is given a lot of emphasis in the breeding goal of the Sahiwal cattle breeding programme as presently defined [14], knowledge of its association with other traits is important as it can is lead to deterioration of other traits of economic importance [56].

Linear type traits are being used to select for conformation, reproduction and longevity [57]. This is because the genetic correlations between some type traits and longevity for cattle populations have been reported to be favorable [4]. Inclusion of type traits leads to the improvement of a cow's conformation, functional and reproductive structure for the cow to meet challenges of increasing production. Apart from the favorable genetic correlation with longevity, type traits are moderately heritable [4] and are recorded early in an animal's life [51] [58].

The benefits of indirect selection for longevity using type traits include reduction of involuntary culling leading to increased profitability because culling is based on milk production [59]. Type traits with great influence on longevity include those related to the udder, feet and legs [4] [11]. Selection for some of these traits has been shown to improve longevity and even 305 milk yields [4]. Generally, indirect selection for longevity based on linear type traits will not yield significant changes in these traits due to low genetic correlations. Nevertheless, due to the low heritability for longevity, indirect gain due to selection on type traits that have high heritability estimates can yield up to $20 \%$ more gains in longevity compared to direct selection [4]. Therefore, indirect selection for longevity based on type traits may not be very efficient, but is justifiable since these traits are measured early in life.

In the Kenyan Sahiwal cattle population, type traits are not routinely recorded, but the breeding objective includes traits such as production and fertility traits [14]. However, the genetic correlations in the current breeding objective traits and longevity have not been estimated. It is therefore not known whether correlated response in longevity due to selection on the current selection criteria would be favorable or not. Reproductive traits, apart from being important determinants of herd productivity, have been shown to contribute to longevity in cattle herds [11]. Poor reproductive performance leads to prolonged calving intervals [60] and sometimes also increased involuntary culling. Consequently, a cow produces less milk and fewer calves per year and its lifetime. Increased involuntary culling because of sub-optimal fertility can also lead to high replacement costs [51] thereby lowering net returns from cattle enterprises. Therefore, breeding objectives of many selection programmes across the world are being changed to include functional traits such as health and fertility [1] [61].

Numerous studies have reported the genetic relationship between fertility traits and milk yield [62] with only a few reporting on the association between fertility and longevity [11] [63] [64]. [11] found that reproductive traits were significantly associated with functional longevity. Cows that required more services per conception, had more days open and days from first service to concep- 
tion were more likely to be involuntarily culled. A selection programme focusing on primarily increasing milk yield leads to deterioration in fertility [57] [61]. This is due to increase in peak yield which is associated with a negative energy balance at peak yield. It is therefore expected that in such a breeding programme, increasing milk yield will lead to increased involuntary culling due to poor fertility, thus compromising longevity and herd productivity [65].

\subsection{Modelling of Longevity}

The global trend in cattle breeding is now to include all economically important traits in the breeding objective. Functional traits such as longevity, disease, fertility and type traits are now featuring prominently in the breeding objective of many breeding programmes [9] [66] [67]. This is because the economic value of longevity is reported to be up to half of that of production traits [68]. In the quest to include longevity in the breeding objective, the first step has been to come up with a definition of longevity. To date, longevity is variously defined as length of productive life, lifetime milk production, herd life, total number of lactations and survival from birth or first calving to a certain age [69] [70]. The second challenge has been the choice of an appropriate analysis procedure. Here the challenge is basically because factors affecting longevity change over time.

Characteristically, longevity is a threshold trait, and displays distinct categorical phenotypes. Threshold traits are influenced by an underlying continuous liability [19]. For longevity data, most animals in a herd are found in early lactation, hence the data is usually skewed to the left [71]. Factors that influence longevity differ over time depending on prevailing environmental conditions and are therefore time dependent [29] [72]. Survival data can be censored or uncensored. Events like death or culling may be known to have occurred and therefore will be uncensored. On the other hand, such events may not have been recorded because they are not known to have occurred. If animals are alive at the time of analysis, they will be included in the evaluation and are therefore regarded as censored [28]. These complex characteristics or features of survival data require careful consideration and choice of the appropriate modelling strategies in order to discover all phenotypic, additive and environmental variance [73]. Approaches used in the analysis of longevity include linear models [4] [35]. This method has been used for longevity measures defined quantitatively such as lifetime milk yield, age from birth or calving to last day in milk and total days in lactation. Other models include random regression [37], threshold, proportional hazard and random regression models [6].

\subsection{Linear Models}

This approach accounts for censored data or records of cows which are still alive at the time of analysis. Survival of an animal to a predefined age or time period is used. The time period or age $t$, is pre-determined on a time scale and the record of each animal is assigned a 1 or 0 , for successful survival to that age or not, re- 
spectively. The model is as follows:

$$
y_{i j}(t)=\mu+s_{i}+e_{i j}
$$

where $y_{i j}(t)=0$ if the jth progeny of the ith sire did not survive to time $t$ and 1 if it was alive at that time. $\mu$ is the overall popualtion mean, $s_{i}$ is the breeding value of the ith sire on the binary scale and $e_{i j}$ are random residuals. This approach to modelling longevity has been applied to Czech Fleckvieh [9], South African Jerseys [16] among other cattle populations [31] [74]. This approach is simple and can accommodate univariate as well as multivariate animal, sire or maternal grandsire models. The drawback of this model is that it makes unrealistic assumption that data are continuous and are normally distributed [75]. Animals at different ages before the pre-determined time point are treated the same way, leading to erroneous results [27]. Factors that influence longevity over the time period are not considered, since survival times are derived from a product [76].

Linear models are more appropriate in analyzing continuous traits such as milk yield rather than binary traits. This is the caution that was taken by [4]. In this study measure of longevity was continuous for example. lifetime milk yield, age from birth or first calving to last day in milk, total days in milk over all lactations were analyzed using linear models, while measures of longevity related to survival were analyzed using threshold models. This was necessary because the use of linear model BLUP was inappropriate because with categorical, data breeding values and residuals would not be independent of each other [77].

\subsection{Random Regression Models}

Random regression models model additive genetic values as a function of an observed dependent variable through a set of random coefficients. In modelling survival data using random regressions, animal records are assigned binary units (0 or 1$)$ if it survived a lactation or a month after calving. A linear model with random regressions for additive animal effect as random effects is then fitted for genetic evaluation and breeding values generated for any point in the trajectory [6] [32]. A univariate random regression model is described as follows:

$$
y_{i j k l m n o: t}=(Y S: H t)_{i j}+(Y S A P: t)_{i k l}+r(a, x m 1)_{n}+r(p e, x, m 2)_{k}+\mathrm{e}_{i j k l m n o: t}
$$

where $y_{i j k l m n o: t}$ is the $\mathrm{n}^{\text {th }}$ observation of the $\mathrm{k}^{\text {th }}$ animal at time $\mathrm{t}$ of the $\mathrm{i}^{\text {th }}$ fixed effect and $j^{\text {th }}$ group, YS is the $\mathrm{i}^{\text {th }}$ year-season of first calving, $\mathrm{H}$ is the $\mathrm{j}^{\text {th }}$ herd, $\mathrm{A}$ is the $\mathrm{k}^{\text {th }}$ age at first calving class, $\mathrm{P}$ is the production level, $y_{i j k l m n o: t}=\sum_{i=0}^{m_{1}} a_{k l} x_{i j k: l}$ is notation for random regression, where a is the additive genetic effect for the $\mathrm{kth}$ animal, $\mathrm{x}$ are orthogonal polynomials of time $\mathrm{t}$, after calving, $\boldsymbol{a}$ is the random regression coefficients for additive genetic effects for animal n, $\boldsymbol{p} \boldsymbol{e}$ are the random regression coefficients for permanent environmental effects for animal $n$ and $\mathrm{e}_{i j k l m n o: t}$ are random residuals. Random regression models are more robust to effects of censoring data [78] and are closer to proportional hazard models and generalized linear models. They can also handle multiple traits [79]. 


\subsection{Proportional Hazard Models}

Proportional hazard (PH) models model survival as the probability that an animal will survive past a specified time $t$, and the hazard function, which is the instantaneous rate of failure [80]. The survival function and the hazard functions in PH modelling differentiate between a cow that dies exactly at time $t$, and one that was last alive at time $t$, and may have survived on. PH models make the assumption that the hazard rate or risk is a function of time-dependent baseline hazard and an exponential function of a series of explanatory variables i.e. covariates [81]. PH models may not result in the best fit to data and therefore may not accurately estimate the performance of future offspring of an individual [82]. They also make the assumption that survival is the same trait throughout the lifetime, although correlations between parities 1 to 3 have been reported to be less than unity. Another limitation is their inability to account for non-random mating among animals [83] and cannot handle multiple traits [36] [82]. Despite these limitations they are able to handle censored data and can accommodate non-normal data distribution well and incorporate time-dependent environmental effects [27]. Common PH models include Weibull and Cox models, with the former being more popular.

\subsection{Threshold Models}

In threshold modelling, survival is considered as a binary trait $(0=$ dead at time $t$ and $1=$ alive at time $t$ ). Threshold models include sequential threshold models, threshold repeatability models, and threshold cross-sectional models. Threshold models have been used to evaluate survival to weaning in pigs [84], survival in dairy cattle [82]. Threshold models have been used to analyze measures of longevity related to survival such as survival from birth or first calving to predetermined age [4]. The major limitation of threshold models is that heritability estimates are from an underlying continuous scale, and their effect on rate of genetic gain may be similar to that from linear models [83]. However, they are capable of handling multiple traits and can handle large datasets.

\subsection{Model Comparison}

Linear, threshold and random regression models yield lower estimates of heritability, ranging from 0.01 to 0.18 [4] [37] than proportional hazard models $(0.15$ to 0.22 ) on the original scale. However, the former group of models is able to accommodate multiple traits and therefore can produce genetic correlations of longevity with other indicator traits [12]. [82] found that threshold models yielded higher heritability estimates (0.04) compared to those obtained from linear repeatability and cross-sectional models (0.02). In terms of accuracy of evaluations, the models were compared based on the correlation between true and estimated breeding values for proportion of sire's daughters that survived to a specified age and sire ranking. The correlation for Weibull models remained constant over time, but increased over time for linear and random regression 
models, though they were lower than for the former models. The models also differed in terms of ranking of sires. For instance, linear models and Weibull models had similar sire rankings compared to proportional hazard models. Multi-trait models were also found to be superior in terms of predicting survival of daughters up to a certain age compared to Weibull models [32]. In this study, Weibull models showed poor prediction of proportion of daughters of sires in early cow lifetime than multiple trait models.

In general, linear and threshold models have been found to be superior to Weibull models when sire breeding values are estimated when predicting survival to 365 days from first calving [82]. Weibull models are better when predicting functional longevity while linear random regression and linear multiple trait models are the models of choice when predicting overall survival [32]. Linear models are however favored when studying the predictive ability of sire estimated breeding values of survival to a particular age, since this is better measured by average longevity instead of functional longevity. Threshold models are more appropriate for analyzing binary survival than linear models [83], while linear multiple traits and random regression models resulted in inferior statistical correctness (inferior model fit) [32]. Threshold sire models also result in higher heritability estimates than linear sire models

\section{Heritability Estimates for Longevity}

Longevity is the single most important functional trait in cattle breeding with a high economic value but has very low heritability. [6] reported heritability estimates for longevity defined variously based on the length of time interval for survival after first calving as ranging from 0.002 to 0.031 . In another study, [4] reported estimates ranging from 0.05 to 0.07 for longevity defined as total milk production over all lactations, number of lactations initiated, total number of days in lactation over all lactations, time between birth and last milk recording in months; and time from first calving to last milk recording in months. In another study, [4] reported heritability estimates of 0.06 to 0.09 using the linear model and 0.05 to 0.18 for traits using the threshold model for Brazilian Holstein cows. Other studies that have reported low to moderate estimates of heritability for longevity include [54] and [85]. Thus, heritability estimates for longevity regardless of how the trait is defined or analyzed are low, implying that direct selection may not yield significant gains [4].

It is however important to note that estimates of heritability for longevity depend on the model used for analysis [86]. For instance, estimates from proportional hazard models can be expressed either on a log-linear scale, original scale or as effective heritability [75]. Heritability estimates from linear, threshold or random regression models are usually lower than those from proportional hazard models [40] [86]. Estimates ranging from 0.01 to 0.03 for length of productive life defined as a binary trait were reported for South African Jerseys from multivariate linear sire and animal models [35]. Slightly higher estimates (0.06) 
using a linear animal model were reported for South African Holsteins [50]. Higher estimates from linear animal models ranging from 0.05 [9] to 0.1 [87] have been reported for Czech Fleckvieh and American Holsteins, respectively.

Estimates of heritability based on random regression models are reported for monthly survival [88]. This way if an animal survived to month $n+1$, it is considered alive and assigned a score of 100 [89]. A cow culled in month $\mathrm{n}$ is assigned a score of 0 [37]. Monthly survival heritability estimates have been reported to range from 0.002 to 0.011 [37] reported estimates ranging from 0.002 to 0.031 [90]. Cumulative heritability estimates over the entire life span ranged from 0.115 to 0.149 [37]. Higher ranges for monthly estimates of 0.02 to 0.181 [33] and 0.01 to 0.07 [36] for British dairy cattle have been reported. [32] reported higher estimates, ranging from 0.12 to 0.36 for Canadian Jersey cattle.

Heritability estimates for longevity estimated using threshold models have been reported for various cattle populations. [82] reported an estimate of 0.04 for Norwegian Red Holsteins while [4] found a value of 0.15 for Brazilian Holsteins. Higher estimates for beef cattle ranging from 0.08 [88] to 0.30 [91] have been reported. The differences between estimates for dairy and beef cattle could partly be due to differences in definition of longevity and breeding objective. [92] reported an estimate of 0.11 using a sequential threshold model. In general threshold models yield higher heritability estimates than linear models.

Heritabilitys obtained from proportional hazard models estimated on the original scale are usually higher than those on log-linear scale, and are similar to those from linear models [93]. Estimates from log-linear scale range from 0.05 to 0.10 [70] and 0.15 to 0.20 on the original scale [70]. using a Weibull Proportional hazard model, [94] reported heritability estimate of 0.05 on the log scale for Pinzgau cattle in Croatia, similar to 0.04 reported by [56] and [95]. Higher estimates of 0.16 to 0.22 [96], 0.12 [97]) and 0.21 to 0.22 [30] on the original scale have also been reported. The wide variation in estimates of heritability could be attributed to differences in magnitudes of genetic variation for longevity, differences in accuracy of sire identification, record keeping and precision of data analysis and model used [70].

\section{Genetic Correlations between Longevity and Performance Traits}

Estimation of genetic parameters for traits expressed early in an animal's life and their correlation with longevity can help to identify a selection criterion [95], which enables the inclusion of longevity in the breeding goal of the Kenyan Sahiwal population. This will lead to development of a more comprehensive breeding objective ensuring sustainable genetic improvement of the breed. Genetics correlations between longevity and performance traits depend on the type of trait population being studied and the way longevity is defined. For instance, [4] reported that genetic correlations between various definitions of longevity and linear type traits ranged from -0.39 to 0.31 . In this study, longevity was defined either as total milk yield over all lactations, number of lactations initiated, 
time between birth and last milking record in months, time between first calving and last milking record in months or total number of days in lactation over all lactations. Longevity defined as total number of days in lactation over all lactations had the strongest genetic correlation with type traits such as weight $(-0.38)$, stature $(-0.31)$, topline $(-0.25)$, chest width $(-0.27)$, udder width $(-0.30)$ among others. Longevity defined this way was also positively correlated to rump angle, bone quality, udder height and udder depth [4]. Other studies reported genetic correlations between rump width and number of days in lactation, number of lactations initiated and time between birth and last milking record of $-0.27,-0.15$ and -0.29 , respectively, in Jersey cattle [31].

Genetic correlations between fore udder and longevity traits have been reported to be low, ranging from 0.06 to -0.08 [4] [9] [31] suggesting that selection based on fore udder attachment, fore teat placement and fore teat length has little influence on longevity. However, longevity was moderately correlated with rear udder height ( 0.16 and 0.20 ), indicating that selection based on these traits may favor the permanence of cows in the herd. Udder depth had the highest positive genetic correlations with measures of longevity, ranging from 0.17 to $0.31[4]$.

The choice of which trait to use a selection criterion for longevity depends on its heritability, cost, ease of measurement and time required to obtain its information. Based on the study by [4], selection for udder depth in the first lactation, since this trait has higher heritability ( 0.23 to 0.26$)$ than longevity measures $(0.05$ to 0.07 ), has a lower cost as it is collected early in life and presents moderate correlations with longevity ( 0.17 to 0.31 ), and, therefore, can be used as a proxy for indirect selection for longevity.

\section{Inbreeding Depression for Longevity and Other Survival Related Traits}

The current quest of cattle improvement programmes world over is to improve longevity alongside other traits of economic importance. Despite its economic importance to cattle farming, studies of inbreeding depression on longevity are very few [98]. However, longevity and other correlated traits are negatively affected by inbreeding in livestock populations. For instance, longevity and reproductive performance decreases while, rate of disposal or loss of replacement heifers before first calving [99], age at puberty increases due to inbreeding through reduced growth [16]. For every increase of $1 \%$ in inbreeding, productive life was reported to decrease by about 13 days [17]. Cows with high inbreeding level also have a higher risk of being culled [18].

In cattle dairy cattle the detrimental effects of inbreeding on production traits are well documented. A $1 \%$ increase in inbreeding coefficient level has been found to decrease milk production by $37 \mathrm{~kg}$ [17]. A similar increase in inbreeding resulted in a $15.42 \mathrm{~kg}$ milk yield in South African Jersey cattle [94]. Milk component traits, butter fat and protein yield were also negatively affected (Table 1). 
Table 1. Heritability estimates for various definitions of longevity.

\begin{tabular}{|c|c|c|c|c|}
\hline Breed & $\mathbf{N}$ & Trait & Heritability & Author(s) \\
\hline German Holsteins & $11,106,125$ & $\mathrm{FL}$ & $0.03-0.05$ & Wiebelitz et al. (2014) \\
\hline Czech Holsteins & 57,803 & NL & 0.05 & Zavadilova and Stipkova (2012) \\
\hline Czech Holsteins & 57,803 & NLF & 0.04 & Zavadilova and Stipkova (2012) \\
\hline Czech Holsteins & 57,803 & LPL\&FLPL & 0.03 & Zavadilova and Stipkova (2012) \\
\hline South African Jersey & 181,269 & FHL & $0.02-0.03$ & Du Toit (2011) \\
\hline South African Jersey & 181,269 & FHL & $0.01-0.03$ & Du Toit (2011) \\
\hline Norwegian Red & 808,750 & SS & $0.02-0.03$ & Holtsmark et al. (2009) \\
\hline Czech Fleckvieh & 58,493 & FL & 0.05 & Zavadilova et al. (2009) \\
\hline South African Holsteins & 34,201 & NL & 0.06 & Setati et al. (2004) \\
\hline Japanese Holsteins & 117,404 & $\mathrm{HL}$ & $0.12-0.12$ & Sasaki et al. (2012) \\
\hline Tunisian Holsteins & 36,888 & $\mathrm{FL}$ & 0.19 & M’hamdi et al. (2010) \\
\hline Japanese Holsteins & 158,719 & FLPL & $0.05-0.10$ & Terawaki and Ducrocq (2009) \\
\hline Norwegian Red & 808,750 & PL & 0.04 & Holtsmark et al. (2009) \\
\hline Slovak Pinzgau & 21,985 & FLPL & 0.05 & Mészáros et al. (2008) \\
\hline Spanish Holstein-Friesian & 21,058 & $\mathrm{FL}$ & $0.05-0.07$ & Chirinos et al. (2007) \\
\hline French Holsteins & 629,716 & $\mathrm{FL}$ & 0.22 & Ducrocq (1997) \\
\hline Brazilian Holsteins & - & SGA & $0.09-0.15$ & Kern et al. (2014) \\
\hline Norwegian Red & 808,750 & SS & 0.04 & Holtsmark et al. (2009) \\
\hline Norwegian Red & 808,750 & SS & 0.04 & Holtsmark et al. (2009) \\
\hline South African Beef Breeds & - & $\mathrm{FL}$ & 0.08 & Van der Westhuizen et al. (2001) \\
\hline Canadian Holsteins & 700,000 & $\mathrm{FL}$ & 0.07 & Boettcher et al. (1999) \\
\hline Spanish Holsteins & 96,642 & SNL & 0.11 & Gonzalez-Recio and Alenda (2007) \\
\hline South African Angus & 28,671 & Stayability & $0.24-0.30$ & Maiwashe et al.(2009) \\
\hline Dutch Dairy Cattle & 950,616 & $\mathrm{FL}$ & $0.002-0.01$ & VanPelt and Veerkamp (2014) \\
\hline Canadian Jersey & $1,164,319$ & Stayability & $0.12-0.36$ & Jamrozik et al. (2008) \\
\hline British Holsteins & 24,741 & FL & $0.01-0.07$ & Veerkamp et al. (2001) \\
\hline
\end{tabular}

NL: number of lactations initiated; FLPL: functional length of productive life; FHL: functional herd life; FL: functional longevity; LPL: length of productive life; SNL: survival to next lactation; SS: survival scores; SGA: Survival to given age. 
Though inbreeding depression for production traits in dairy cattle is well documented, not many studies have reported on the effect of inbreeding on longevity of cows [64] [96]). In Canadian cows longevity was reduced by 65 days due to a change in inbreeding of 5\% [17]. Further, cows with high levels of inbreeding were reported to face a higher risk of being culled [18]. There is a need to investigate inbreeding depression in longevity, production and fertility traits in the Kenyan Sahiwal population based on individual level and rate of inbreeding.

\section{Conclusion}

Effects of inbreeding on non-production traits include decreased reproductive efficiency and decreased stay ability. The negative effects on traits related to fitness have been attributed to reduced heterozygosity as inbreeding accumulates [19]. Inbreeding level and rate of inbreeding in the Sahiwal cattle population in Kenya have been found to be on an upward trend and are above 1\% [20]. Inbreeding depression for longevity and other correlated traits should be assessed for the Sahiwal cattle population in Kenya. The current status that a cow can stay in a herd for more than a hundred months is wrong. Ninety-six months is the ultimate number of months recommended from the models. Any extra day from the ninety-six month will be a loss-making enterprise.

\section{Declaration}

We declare no blood samples or animals were mistreated bioethically. Authors didn't have any conflict of interest. The data was collected from a recognized research organization KARLO.

\section{Ethical Approval and Data Availability}

Ethics review has been ensured in this review article which conforms to the ethical standards expected by the Department of Biological Sciences and Egerton University and to the code of ethical principles and standards. It has assisted staff and my co-authors in reflecting upon and promoting the best possible ethical research practice.

\section{Conflicts of Interest}

The authors declare no conflicts of interest regarding the publication of this paper.

\section{References}

[1] Banga, C.B., Neser, F.W.C. and Garrick, D.J. (2013) Derivation of Economic Values of Longevity for Inclusion in the Breeding Objectives for South African Dairy Cattle. International Proceedings of Chemical Biological and Environmental Engineering, 60, 69-73.

[2] Varona, L., Moreno, C. and Alltarriba, J. (2012) Genetic Correlation of Longevity with Growth, Post-Mortem, Docility and Some Morphological Traits in the Pirenaica Beef Cattle Breed. Animal, 6, 873-879. 
https://doi.org/10.1017/S1751731111002072

[3] Garcia, J., Anderson, D.P., Herring, A.D. and Riley, D.G. (2015) Economic Analysis of Selecting for Cow Longevity. Presentation at the Southern Agricultural Economics Association's 2015 Annual Meeting, Atlanta, 31 January-3 February 2015, 532-536.

[4] Kern, E.L., Cobuci, J.A., Costa, C.N. and Pimentel, C.M.M. (2014) Factor Analysis of Linear Type Traits and Their Relation with Longevity in Brazilian Holstein Cattle. Asian Australasian Journal of Animal Science, 27, 784-790.

https://doi.org/10.5713/ajas.2013.13817

[5] Kern, E.L., Cobuci, J.A., Costa, C.N., McManus, C.M. and Neto, J.B. (2015) Genetic Association between Longevity and Linear Type Traits of Holstein Cows. Scientia Agricola, 72, 203-209. https://doi.org/10.1590/0103-9016-2014-0007

[6] Van Pelt, M.L., Meuwissen, T.H.E., de Jong, G. and Veerkamp, R.F. (2015) Genetic Analysis of Longevity in Dutch Dairy Cattle Using Random Regression. Journal of Dairy Science, 98, 4117-4130. https://doi.org/10.3168/jds.2014-9090

[7] Lagrotta, M.R., Euclydes, R.F., Verneque, R.S., Santana-Júnior, M.L., Pereira, R.J. and Torres, R.A. (2010) Relationship between Morphological Traits and Milk Yield in Gir Breed Cows. Pesquisa Agropecuária Brasileira, 45, 423-429. (In Portuguese) https://doi.org/10.1590/S0100-204X2010000400011

[8] Melo, A., Carolina, G.D., Sheila, C.C. and Wagner, R. (2014) Adolescent Adaptive Behaviour Profiles in Williams-Beuren Syndrome, Down Syndrome, and Autism Spectrum Disorder. Child and Adolescent Psychiatry and Mental Health, 11, Article No. 40. https://doi.org/10.1186/s13034-017-0177-0

[9] Zavadilová, L., Nemcová, E., Štípková, M. and Bouška, J. (2009) Relationships between Longevity and Conformation Traits in Czech Fleckvieh Cows. Czech Journal of Animal Science, 54, 387-394. https://doi.org/10.17221/1685-CJAS

[10] Zavadilova, L., Sitpkova, M., Nemcova, E., Bouska, J. and Matejickova, J. (2009) Analysis of the Phenotypic Relationships between Type Traits and Functional Survival in Czech Fleckvieh Cows. Czech Journal of Animal Science, 54, 521-531. https://doi.org/10.17221/29/2009-CJAS

[11] Sewalem, A., Miglior, F., Kistemaker, G.J., Sullivan, P. and Van Doormaal, B.J. (2008) Relationship between Reproduction Traits and Functional Longevity in Canadian Dairy Cattle. Journal of Dairy Science, 91, 1660-1668. https://doi.org/10.3168/jds.2007-0178

[12] Kern, E.L., Cobuci, J.A., Costa, C.N. and Ducrocq, V. (2017) Phenotypic Relationships between Type Traits and Productive Life Using a Piecewise Weibull Proportional Hazard Model. Scientia Agricola, 75, 470-478.

https://doi.org/10.1590/1678-992X-2017-0153

[13] Roessler, R., Ilatsia, E.D. and Valle Zárate, A. (2010) Optimized Breeding Strategies for the Local Sahiwal Cattle in Kenya: Use Values and Important Breeding Traits. Fifth All African Conference on Animal Agriculture, Addis Ababa, 25-28 October 2010, 25-28.

[14] Ilatsia, E.D., Migose, S.A., Muhuyi, W.B. and Kahi, A.K. (2011) Sahiwal Cattle in Semi arid Kenya: Genetic Aspects of Growth and Survival Traits and Their Relationship to Milk Production and Fertility. Tropical Animal health and Production, 43, 1572-1582. https://doi.org/10.1007/s11250-011-9845-x

[15] Ilatsia, E.D., Roessler, R., Kahi, A.K., Piepho, H.-P. and Zárate, V. (2012) Production Objectives and Breeding Goals of Sahiwal Cattle Keepers in Kenya and Implications for a Breeding Programme. Tropical Animal Health and Production, 44, 519-530. https://doi.org/10.1007/s11250-011-9928-8 
[16] Du Toit J., van Wyk, J.B. and Maiwashe, A. (2012) Assessment of Inbreeding Depression for Functional Herd Life in the South African Jersey Breed Based on Level and Rate of Inbreeding. South African Journal of Animal Science, 42, 55-62. https://doi.org/10.4314/sajas.v42i1.7

[17] Canadian Dairy Network (CDN) (2008) Subject: Quantifying Inbreeding Depression. http://www.cdn.ca

[18] Rokouei, M., VaezTorshizi, R., MoradiShahrbabak, M., Sargolzaei, M. and Sørensen, C. (2010) Monitoring Inbreeding Trends and Inbreeding Depression for Economically Important Traits of Holstein Cattle in Iran. Journal of Dairy Science, 93, 3294-3302. https://doi.org/10.3168/jds.2009-2748

[19] Falconer, D.S. and Mackay, T.F.C. (1996) Introduction to Quantitative Genetics. 4th Edition, Longman Scientific and Technical, Harlow.

[20] Mwangi, S., Muasya, T.K., Ilatsia, E. and Kahi, A. (2016) Assessment of Genetic Viability Using Pedigree Analysis of Sahiwal Breed in Kenya. Animal Genetic Resources, 59, 7-14. https://doi.org/10.1017/S2078633616000199

[21] Van Wyk, J.B., Fair, M.D. and Cloete, S.W.P. (2009) Case Study: The Effect of Inbreeding on the Production and Reproduction Traits in the Elsenburg Dormer Sheep Stud. Livestock Science, 120, 218-224. https://doi.org/10.1016/j.livsci.2006.10.005

[22] Gonzalez-Recio, O. and Alenda, R. (2007) Genetic Relationship of Discrete-Time Survival with Fertility and Production in Dairy Cattle Using Bivariate Models. Genetics Selection and Evolution, 39, 391-404. https://doi.org/10.1186/1297-9686-39-4-391

[23] González-Recio, O., López de Maturana, E. and Gutiérrez, J.P. (2009) Inbreeding Depression on Female Fertility and Calving Ease in Spanish Dairy Cattle. Journal of Dairy Science, 90, 744-5752. https://doi.org/10.3168/jds.2007-0203

[24] Muhuyi, W.B. (1997) A Comparison of the Productivity of Kenya Sahiwal and Their Crosses in Large Scale Dairy Dual Purpose and Beef Production Systems. PhD Thesis, University of Nairobi, Nairobi.

[25] Ilatsia, E.D., Muasya, T.K., Muhuyi, W.B. and Kahi, A.K. (2007) Genetic and Phenotypic Parameters and Annual Trends for Milk Production and Fertility Traits of the Sahiwal Cattle in Semi Arid Kenya. Tropical Animal Health Production, 39, 37-48. https://doi.org/10.1007/s11250-006-4408-2

[26] Aby, B.A., Aass, L., Sehested, E. and Vangen, O. (2012) A Bio-Economic Model for Calculating Economic Values of Traits for Intensive and Extensive Beef Cattle Breeds. Livestock Science, 143, 259-269. https://doi.org/10.1016/j.livsci.2011.10.003

[27] Ducrocq, V., Quaas, R.L., Pollak, E.J. and Casella, G. (1988) Length of Productive Life of Dairy Cows. 2. Variance Component Estimation and Sire Evaluation. Journal of Dairy Science, 71, 3070-3079. https://doi.org/10.3168/jds.S0022-0302(88)79907-5

[28] Beswick, V., Cheek, L. and Ball, J. (2004) Statistics Review 12: Survival Analysis. Critical Care, 8, 389-394. https://doi.org/10.1186/cc2955

[29] Flynn, R. (2012) Approaches for Data Analysis: Survival Analysis. Journal of Clinical Nursing, 21, 2789-2797. https://doi.org/10.1111/j.1365-2702.2011.04023.x

[30] Bünger, A. and Swalve, H.H. (1999) Analysis of Survival in Dairy Cows Using Supplementary Data on Type Scores and Housing Systems. Interbull Bulletin No. 21, Uppsala, 128-135.

[31] Zavadilová, L. and Štípková, M. (2012) Genetic Correlations between Longevity and Conformation Traits in the Czech Holstein Population. Czech Journal of Animal 
Science, 57, 125-136. https://doi.org/10.17221/5566-CJAS

[32] Jamrozik, J., Fatehi, J. and Schaffer, L.R. (2008) Comparison of Models for Genetic Evaluation of Survival Traits in Dairy Cattle: A Simulation Study. Journal of Animal Breeding and Genetics, 125, 75-83. https://doi.org/10.1111/j.1439-0388.2007.00712.x

[33] Forabosco, F., Jakobsen, J.H. and Fikse, W.F. (2009) International Genetic Evaluation for Direct Longevity in Dairy Bulls. Journal of Dairy Science, 92, 2338-2347. https://doi.org/10.3168/jds.2008-1214

[34] Holtsmark, M., Heringstad, B. and Ødegård, J. (2009) Predictive Abilities of Different Statistical Models for Analysis of Survival in Dairy Cattle. Journal of Dairy Science, 92, 5730-5738. https://doi.org/10.3168/jds.2009-2132

[35] Du Toit, J. (2011) A Genetic Evaluation of Productive Herd Life in Dairy Cattle. PhD Dissertation, University of the Free State, Bloemfontein.

[36] Veerkamp, R.F., Brotherstone, S., Engel, B. and Meuwiwissen, T.H.E. (2001) Analysis of Censored Survival Data Using Random Regression Models. Animal Science, 72, 1-10. https://doi.org/10.1017/S1357729800055491

[37] Van Pelt, M.L. and Veerkamp, R.F. (2014) Genetic Analysis of Longevity in Dutch Dairy Cattle Using Random Regression. Proceeding of the 10 th World Congress of Genetics Applied to Livestock Production, Vancouver, 17-22 August 2014, 17-22.

[38] Gutiérrez, J.P., Cervantes, I. and Goyache, F. (2009) Improving the Estimation of Realized Effective Population Sizes in Farm Animals. Journal of Animal Breeding and Genetics, 126, 327-332. https://doi.org/10.1111/j.1439-0388.2009.00810.x

[39] Maiwashe, A., Nephawe, K.A. and Theron, H.E. (2009) Analysis of Stay Ability in South African Angus Using a Threshold Model. South African Journal of Animal Science, 39, 55-60. https://doi.org/10.4314/sajas.v39i1.43546

[40] Sewalem, A., Kistemaker, G.J. and Van Doormaal, B.J. (2005) Relationship between Type Traits and Longevity in Canadian Jerseys and Ayrshires Using a Weibull Proportional Hazards Model. Journal of Dairy Science, 88, 1552-1560. https://doi.org/10.3168/jds.S0022-0302(05)72824-1

[41] Wesseldijk, B. (2004) Secondary Traits Make Up 26\% of Breeding Goal. Holstein International, 11, 8-11.

[42] Essl, A. (1998) Longevity in Dairy Cattle Breeding: A Review. Livestock Production Science, 57, 79-89. https://doi.org/10.1016/S0301-6226(98)00160-2

[43] Schneider, M.D., Monardes, P.H. and Cue, R.I. (1999) Effects of Type Traits on Functional Herd Life in Holstein Cows. Interbull Bulletin, 21, 111-116.

[44] Miglior, F., Muir, B.L. and Van Doormaal, B.J. (2005) Selection Indices in Holstein Cattle of Various Countries. Journal of Dairy Science, 88, 1255-1263. https://doi.org/10.3168/jds.S0022-0302(05)72792-2

[45] Meyn, K. and Wilkins, J.V. (1974) Breeding for Milk in Kenya with Particular Reference to the Sahiwal Stud. World Animal Review, 11, 24-30.

[46] Sewalem, A., Kistemaker, G.J., Ducrocq, V. and Van Doormaal, B.J. (2005) Genetic Analysis of Herd Life in Canadian Dairy Cattle on a Lactation Basis Using a Weibull Proportional Hazards Model. Journal of Dairy Science, 88, 368-375. https://doi.org/10.3168/jds.S0022-0302(05)72696-5

[47] Wolfová, M., Wolf, J., Kvapilík, J. and Kica, J. (2007) Selection for Profit in Cattle: I. Economic Weights for Purebred Dairy in the Czech Republic. Journal of Dairy Science, 90, 2442-2455. https://doi.org/10.3168/jds.2006-614

[48] Hazel, L.N. (1943) The Genetic Basis for Constructing Selection Indexes. Genetics, 
28, 476-490.

[49] Vargas, B., Groen, A.F., Herrero, M. and Van Arendonk, J.A.M. (2002) Economic Values for Production and Functional Traits in Holstein Cattle of Costa Rica. Livestock Production Science, 75, 101-116. https://doi.org/10.1016/S0301-6226(01)00305-0

[50] Setati, M.M., Norris, D., Banga, C.B. and Benyi, K. (2004) Relationships between Longevity and Linear Type in Holstein Cattle Population of Southern Africa. Tropical Animal Health and Production, 36, 807-814. https://doi.org/10.1023/B:TROP.0000045965.99974.9c

[51] Kadarmideen, H.N. and Wegmann, S. (2003) Genetic Parameters for Body Condition Score and Its Relationship with Type and Production Traits in Swiss Holsteins. Journal of Dairy Science, 86, 3685-3693. https://doi.org/10.3168/jds.S0022-0302(03)73974-5

[52] Queiroz, A.S. and Mcallister, A.J. (2002) Avaliação do tipo de descarte de vacassobre a rentabilidade de rebanhosleiteiros no Estado de Kentucky. Journal of Dairy Science, 72, 3765-3770.

[53] Brito, F.V., Sargolzaei, M., Braccini Neto, J., Cobuci , J.A., Pimentel, C.M., Barcellos, J. and Schenkel, F.S. (2013) In-Depth Pedigree Analysis in a Large Brazilian Nellore Herd. Genetics and Molecular Research, 12, 5758-5765.

https://doi.org/10.4238/2013.November.22.2

[54] Ahlman, T., Berglund, B., Rydhmer, L. and Strandberg, E. (2011) Culling Reasons in Organic and Conventional Dairy Herds and Genotype by Environment Interaction for Longevity. Journal of Dairy Science, 94, 1568-1575.

https://doi.org/10.3168/jds.2010-3483

[55] Forabosco, F., Bozzi, R., Filippini, F., Boettcher, P., Van Arendonk, J.A.M. and Bijma, P. (2006) Linear Model vs. Survival Analysis for Genetic Evaluation of Sires for Longevity in Chianina Beef Cattle. Livestock Science, 101, 191-198. https://doi.org/10.1016/j.livprodsci.2005.11.010

[56] Vander Linde, C., Dejong, G., Simai, S.Z., Gombacsi, P. and Wellisch, P. (2006) Genetic Evaluation for Longevity in Hungary. Interbull Bulletin, 35, 3-8.

[57] Albarrán-Portillo, B. and Pollott, G.E. (2013) The Relationship between Fertility and Lactation Characteristics in Holstein Cows on United Kingdom Commercial Dairy Farms. Journal of Dairy Science, 96, 635-646.

https://doi.org/10.3168/jds.2012-5632

[58] Cruickshank, J., Weigel, K.A., Dentine, M.R. and Kirkpatrick, B.W. (2002) Indirect Prediction of Herd Life in Guernsey Dairy Cattle. Journal of Dairy Science, 85, 1307-1313. https://doi.org/10.3168/jds.S0022-0302(02)74195-7

[59] Sewalem, A., Miglior, F., Kistemaker, G.J., Sullivan, P., Huapaya, G. and Van Doormaal, B.J. (2007) Modification of Genetic Evaluation of Herd Life from a Three-Trait to a Five-Trait Model in Canadian Dairy Cattle. Journal of Dairy Science, 90, 2025-2028. https://doi.org/10.3168/jds.2006-719

[60] Muasya, T.K., Kariuki, J.N. and Muia, J.M.K. (2011) Population Structure of the Sahiwal Breed in Kenya. Livestock Research for Rural Development, 23, Article No. 186. http://www.lrrd.org/lrrd23/9/muas23186.htm

[61] Sewalem, A., Kistemaker, G.J. and Miglior, F. (2010) Relationship between Female Fertility and Production Traits in Canadian Holsteins. Journal of Dairy Science, 93, 4427-4434. https://doi.org/10.3168/jds.2009-2915

[62] Dube, B., Banga, C.B., Dzama, K. and Norris, D. (2008) Genetic Analysis of Somatic Cell Score and Linear Type Traits in South African Holstein Cattle. South African 
Journal of Animal Science, 8, 229-232. https://doi.org/10.4314/sajas.v38i1.4102

[63] Pérez-Cabal, M.A., García, C., Gonzàlez-Recio, O. and Alenda, R. (2006) Genetic and Phenotypic Relationships among Locomotion Type Traits, Profit, Production, Longevity, and Fertility in Spanish Dairy Cows. Journal of Dairy Science, 89, 1776-1783. https://doi.org/10.3168/jds.S0022-0302(06)72246-9

[64] Sewalem, A., Kistemaker, G.S., Miglior, F. and Van Doormaal, B.J. (2006) Analysis of Inbreeding and Its Relationship with Functional Longevity in Canadian Dairy Cattle. Journal of Dairy Science, 89, 2210-2216.

https://doi.org/10.3168/jds.S0022-0302(06)72291-3

[65] Banga, C.B., Neser, F.W.C. and Garrick, D.J. (2014) Breeding Objectives for Holstein Cattle in South Africa. South African Journal of Animal Science, 44, 199-214. https://doi.org/10.4314/sajas.v44i3.1

[66] Interbull (2014) Description of National Genetic Evaluation Systems for Dairy Cattle Traits as Applied in Different Interbull Member Countries. http://www-interbull.org/ib/geforms

[67] Jairath, L. and Dekkers, J.C.M. (1994) Genetic Parameters of Functional and True Lactational Survival, and Relationships with Milk Production and Conformation Traits in Registered Canadian Holsteins. Journal of Dairy Science, 77, 146.

[68] Vacek, M., Štípková, M., Nemcová, E. and Bouška, J. (2006) Relationships between Conformation Traits and Longevity of Holstein Cows in the Czech Republic. Czech Journal of Animal Science, 51, 327-333. https://doi.org/10.17221/3946-CJAS

[69] Caraviello, D.Z., Weigel, K.A. and Gianola, D. (2004) Analysis of the Relationship between Type Traits and Functional Survival in US Holstein Cattle Using a Weibull Proportional Hazards Model. Journal of Dairy Science, 87, 2677-2686. https://doi.org/10.3168/jds.S0022-0302(04)73394-9

[70] Caraviello, D.Z., Weigel, K.A. and Gianola, D. (2004) Comparison between a Weibull Proportional Hazards Model and a Linear Model for Predicting the Genetic Merit of US Jersey Sires for Daughter Longevity. Journal of Dairy Science, 87, 1469-1476. https://doi.org/10.3168/jds.S0022-0302(04)73298-1

[71] Zavadilová, L., Nemcova, E. and Štípková, M. (2011) Effect of Type Traits on Functional Longevity of Czech Holstein Cows Estimated from a Cox Proportional Hazards Model. Journal of Dairy Science, 94, 4090-4099.

https://doi.org/10.3168/jds.2010-3684

[72] Meszaros, GFuerst, C., Fuerst-Walt, B., Kadlecik, O., Kasarda, R. and Solkner, J. (2008) Genetic Evaluation for Length of Productive Life in Slovak Pinzgau Cattle. Archiv fur Tierzucht, 51, 438-448. https://doi.org/10.5194/aab-51-438-2008

[73] Weigel, K.A., Palmer, R.W. and Caraviello, D.Z. (2003) Investigation of Factors Affecting Voluntary Culling in Expanding Dairy Herds in Wisconsin Using Survival Analysis. Journal of Dairy Science, 86, 1482-1486.

https://doi.org/10.3168/jds.S0022-0302(03)73733-3

[74] Samoré, A.B., Rizzi, R., Rossoni, A. and Bagnato, A. (2010) Genetic Parameters for Functional Longevity, Type Traits, SCS, Milk Flow and Production in the Italian Brown Swiss. Italian Journal of Animal Science, 9, 145-152. https://doi.org/10.4081/ijas.2010.e28

[75] Yazdi, M.H., Visscher, P.M., Ducroq, V. and Thompson, R. (2002) Heritability, Reliability of Genetic Evaluations and Response to Selection in Proportional Hazards Models. Journal of Dairy Science, 85, 1563-1577. https://doi.org/10.3168/jds.S0022-0302(02)74226-4

[76] Vukasinovic, N. (1999) Application of Survival Analysis in Breeding for Longevity. 
Proceedings of the 4th International Workshop on Genetic Improvement on Functional Traits in Cattle, May 1999, France.

[77] Gianola, D. (1982) Theory and Analysis of Threshold Characters. Journal of Animal Sciences, 54, 1078-1096. https://doi.org/10.2527/jas1982.5451079x

[78] Veerkamp, R.F., Brotherstone, S. and Meuwissen, T.H.E. (1999) Survival Analysis Using Random Regression Models. Proceedings International Workshop on EU Concerted Action Genetic Improvement of Functional Traits in Cattle; Longevity. Interbull Bulletin, 21, 36-40.

[79] Jairath, L., Dekkers, J.C.M., Schaeffer, L.R., Liu, Z., Burnside, E.B. and Kolstad, B. (1998) Genetic Evaluation for Herd Life in Canada. Journal of Dairy Science, 81, 550-562. https://doi.org/10.3168/jds.S0022-0302(98)75607-3

[80] Ducrocq, V. (2005) An Improved Model for the French Genetic Evaluation of Dairy Bulls on Length of Productive Life of Their Daughters. Animal Science, 80, 249-256. https://doi.org/10.1079/ASC41720249

[81] Ducrocq, V. (1997) Survival Analysis, a Statistical Tool for Longevity Data. Proceedings 48 th Annual Meeting of the EAAP, Vienna, 25-28 August 1997, 25-28.

[82] Holtsmark, M., Heringstad, B., Madsen, P. and Ødegård, J. (2008) Genetic Relationship between Culling, Milk Production, Fertility, and Health Traits in Norwegian Red Cows. Journal of Dairy Science, 91, 4006-4012. https://doi.org/10.3168/jds.2007-0816

[83] Boettcher, P.J., Jairath, L.K. and Dekkers, J.C.M. (1999) Comparison of Methods for Genetic Evaluation of Sires for Survival of Their Daughters in the First Three Lactations. Journal of Dairy Science, 82, 1034-1044. https://doi.org/10.3168/jds.S0022-0302(99)75324-5

[84] Cechincito, A., Gonzalo-Recio, O., Lopez de Maturana, E., Gallo, L. and Carnier, P. (2010) A Comparison between Different Survival and Threshold Models with Application to Piglet Preweaning Survival in a Dry-Cured Ham Producing Crossbred Line. Journal of Animal Science, 88, 1990-1998.

https://doi.org/10.2527/jas.2009-2460

[85] M’hamd, N., Aloulou, R., Bouallegue, M., Brar, S.K. and Harmouda, M.B. (2010) A Study on Functional Longevity of Tunisian Holstein Dairy Cattle Using a Weibull Proportional Hazard Model. Livestock Science, 132, 173-176. https://doi.org/10.1016/j.livsci.2010.05.011

[86] Tsurata, S., Misztal, I. and Lawlor, T.J. (2005) Changing Definition of Productive Life in US Holstein: Effect on Genetic Correlations. Journal of Dairy Science, 88, 1156-1165. https://doi.org/10.3168/jds.S0022-0302(05)72782-X

[87] Van Westhuizen, R.R., Schoeman, S.J., Jordan, G.F. and Van Wyk, J.B. (2001) Heritability Estimates Derived from Threshold Analysis for Reproduction and Stayability Traits in a Beef Cattle Herd. South African Journal of Animal Sciences, 31, 25-32. https://doi.org/10.4314/sajas.v31i1.3844

[88] Ducrocq, V. (2002) A Piecewise Weibull Mixed Model for the Analysis of Length of Productive Life of Dairy Cows. Proceedings of the 7 th World Congress on Genetics Applied to Livestock Production, Vol. 32, 505-508.

[89] Terawaki, Y. and Ducrocq, V. (2009) Non-Genetic Effects and Genetic Parameters for Length of Productive Life of Holstein Cows in Hokkaido, Japan. Journal of Dairy Science, 92, 2144-2150. https://doi.org/10.3168/jds.2008-1199

[90] Zavadilová, L. and Štípková, M. (2013) Effect of Age at First Calving on Longevity and Fertility Traits for Holstein Cattle. Czech Journal of Animal Science, 58, 47-57. https://doi.org/10.17221/6614-CJAS 
[91] Maiwashe, A., Nephawe, K.A., Van der Westhuizen, R.R., Mostert, B.E. and Theron, H.E. (2006) Rate of Inbreeding and Effective Population Size in Four Major South African Dairy Cattle Breeds. South African Journal of Animal Science, 36, 50-57. https://doi.org/10.4314/sajas.v36i1.3986

[92] Gutiérrez, J.P. and Goyache, F. (2005) A Note on ENDOG: A Computer Program for Analysing Pedigree Information. Journal of Animal Breeding and Genetics, 122, 172-176. https://doi.org/10.1111/j.1439-0388.2005.00512.x

[93] Ducrocq, V. and Sölkner, J. (1998) The Survival Kit'-V3.0, a Package for Large Analyses of Survival Data. 6th World Congress on Genetics Applied to Livestock Production, Vol. 27, 447-448.

[94] Mostert, B.E. (2011) Inbreeding Facts of the South African Jersey Breed. South African Jersey Journal, 60, 40-45.

[95] Queiroz, S.A., Figueiredo, G., Silva, J.A.IIV, Espasandin, A.C., Meirelles, S.L. and Oliveira, J.A. (2007) Estimates of Genetic Parameters of Stayability in Caracu Cattle. Revistas Brasillia Zootecnia, 36, 1316-1323. (In Portuguese) https://doi.org/10.1590/S1516-35982007000600013

[96] Caraviello, D.Z., Weigel, K.A. and Gianola, D. (2003) Analysis of the Relationship between Type Traits, Inbreeding, and Functional Survival in Jersey Cattle Using a Weibull Proportional Hazards Model. Journal of Dairy Science, 86, 2984-2989. https://doi.org/10.3168/jds.S0022-0302(03)73896-X

[97] Buenger, A., Ducrocq, V. and Swalve, H.H. (2001) Analysis of Survival in Dairy Cows with Supplementary Data on Type Scores and Housing Systems from a Region of Northwest Germany. Journal of Dairy Science, 84, 1531-1541. https://doi.org/10.3168/jds.S0022-0302(01)70187-7

[98] Meyn, K. and Wilkins, J.V. (1974) Breeding for Milk in Kenya with Particular Reference to the Sahiwal Stud. World Animal Review, 11, 24-30.

[99] Frigens, N.C., Berg, P., Theilgaard, P., Korsgaard, I.R., Ingvartsen, K.L., Lovendahi, P. and Jensen, J. (2007) Breed and Parity Effects on Energy Balance Profiles through Lactation. Evidence of Genetically Driven Body Energy Change. Journal of Dairy Science, 90, 5291-5305. https://doi.org/10.3168/jds.2007-0173 